\title{
Images of Nature in the Poetry of Abu Al-Qasim Al-Shabbi
}

Yazid Meftah Ali Wahas

Research Scholar

English Department

Aligarh Muslim University

Aligarh, India

yazeedwahas@gmail.com

\begin{abstract}
The article proposes to explore the images of nature in the poetry of Abu Al-Qasim Al-Shabbi. Nature is an essential element that has played a significant part in Arabic Romantic poetry. Nature and Romanticism are synonyms with each other that we can not talk about Romanticism without talking about nature. Al-Shabbi took from it a refuge during hard times where he finds himself in dire need for lap away from the social injustice particularly when his country, Tunisia, was under the French colonialism. According to him, there is a spiritual unity and shared awareness between nature and a man. Al-Shabbi as an Arabic Romantic poet, nature has occupied a place and become an intellectual content in his poetry. He used different images of nature such as morning, evening, night, love and autumn to express his philosophy towards life and people.
\end{abstract}

Keywords: Arabic Romantic poetry, Al-Shabbi, Nature, images. 
Introduction

Romanticism is characterized by a sense of harmony between nature and man. To Romantics, it implied numerous things and offered itself as an artistic work, made by a holy imagination and in symbolic language. Romantics seriously stressed the importance of nature with its visual beauty of the country life-the place where they find their true identity. It became more idealized in which they took from nature a refuge away from the noisy life of the city. Nature is described as a human spiritual regeneration that is destroyed by the formalities of the city. To him, love for nature implies love for humanity and a different view of the world that involved the concept of justice and freedom.

Nature is the favourite subject of all Romantics. They regarded it as a living personality that has given a mystical element to their lives. Nature reflects not only the poet's outer world but also the inner. It provides an entire and sufficient tangible proof to the soul. It embodies all fundamental motives, truths, and rules of conduct. "Nature, thus, in the Romantic view is not primarily a part of external or objective reality, but merely the outer or sense-form of the "inner" or spiritual reality. It is the inner being in terms of sense" (Schütze 59). It is the symbol of the soul that represents all the essential truths, levels of conduct and motives. Nature is the generous womb that grants poets the peace of mind and happiness in the heart.For Al-Shabbi, nature represents the refuge of his hopes and dreams. He sees in the images of nature an echo of his soul and the eternal tranquillity.

Biography of Al-Shabbi.

Abu Al-Qasim Al-Shabbi (1909- 1934) is the greatest Tunisian poet and leader of Arab Romantic movement. He occupied a high place in modern Arabic poetry in twentieth-century. He is known as the poet of green Tunisia, love and life. He was born in Tunisia in the village of 
Al-Shabbiya near Tauzer town. He received his basic education in Qabs town, then he was sent to Al-Zaituna mosque. He studied law at Tunisian Law School and became a lawyer but he never worked in the field of law. His wide reading and love for both English and Arabic literature sharpened his perception and led him to be a poet.He was influenced by the poetry of Al-Mahjar, Apollo and Al-Diwans. Although he practised poetry for short time, he wrote the finest Arabic poetry in the twentieth century. He was suffering from cardiovascular disease which was the key cause of his premature death at 25. Al-Shabbi's poetry represents all characteristics of Romanticism such as love for nature, the glorification of imagination, spontaneity of emotions and revolt against the standards of neoclassical poetry.

Images of Nature

Al-Shabbi is a part of nature and his poetry is one of its images. His poetry reflects the green forests of Tunisia, its oases, deserts and coasts. The melody of his poetry is the voices of Tunisian birds and whistling of its winds. He sees nature as a living being with a soul that we find sometimes static and sometimes terrible and stormy.It is also the friend of love and lovers, and the refuge of the tormented soul where it finds its rest and reassurance.Nature is the world that brings the Romantic poets back to the era of innocence and goodness away from the miserable reality of society.His aim for describing nature is to express himself. He believes in natural life because it provides a kind of happiness and reduces pains of life. Thus, he wants to connect nature's images with human suffering. Nature has many images in Al-Shabbi's poetry such as morning, evening, night, political rebellion, love and autumn. The next section will discuss them in details.

1. The Morning: 
The morning played a good role in Al-Shabbi's poetry. He wrote about the morning in many of his poems such as Dhikra Sabah "A Morning Remembrance", and Al-Sabah Al-Jadid "The New Morning". The features of morning appear in their most beautiful images in his poem Dhikra Sabah "A Morning Remembrance"."He pictures the countryside awakening in the morning, a magical, breathtaking vision, a worthy testimony to the glory of God. He cries ecstatically to his feelings to bind him to the holy beauty of this morning awakening, for in that bondage he will find artistic freedom" (Speight 183). He writes:

God sanctified the memory of a magical morning in the shadow of a beautiful forest.

As the breeze was dancing drunk on the roses and the wet plant. And the fog of the mountains flowed in a wonderful direction on the meadows of the plains. And the songs of the Shepherds echo in the valleys, mountains, and hills. (Al-Shabbi 386)

However, the feeling transcends the sensual image. The poet goes to describe his beautiful lover as she roams in a wonderful atmosphere. Thus, the poem describes the morning, the beautiful angel, and the poet's aspirations, dreams, and thoughts.In the same poem he writes:

And the beautiful angel is between basil

And grass and shady oaks

She sings with the birds in the jungle

And looking for a lazy fog

And the feeling of the angel is dancing in flowers

Light and gentle breeze. (Al-Shabbi 386) 
In the poem, Min AghaniAlruea"From the Shepherds' Songs", "the poet describes the morning that comes slowly to awaken the life that still in its sleeping. The breezes move the dry leaves and make them dance when they receive the delegation of the morning that began to roam around life to be energized" (Al-Bitar 28). Here, the world woke up after the morning had breathed into it the spirit of life with the splendour of its light.The flower gives life its sweetness and aroma, the birds give it its rhythms, and the water gives it its freshness and survival.

The morning comes singing for sleepy life and hills dream in the shadow of swaying branches The dry leaves of flowers dance. the light roared in those dark breaks. (qtd. in Al-Bitar 28).

\section{The Evening:}

Evening is another image of nature in the poetry of Al-Shabbi. He used it to express his sadness, depression and alienation. "Indeed, the evening expresses the end of the hard day, a moment to rest and lie down, a moment when family and friends gather, but his evening is full of sadness, sorrow and heartbreak"(Sabiha \& Naima np). It is a source of dreams and the end of fatigue and struggles during the daytime."The evening comes to existence, shading it with its colour and kissing it, but it is the kiss of death for roses" ( Al-Bitar 29). Moreover, Speight comments, “In Al-Masa' Al-Hazin', 'The Sad Evening', the pastoral beauty of rural life settling for the night is set as a foil for the poet's hope, which alone is unable to find repose" (183).

The sad evening prevailed the existence and in his palm there is a piano that cannot be seen And in his mouth are smiles of sadness 
and in his eyes of it is heartbreaks of years

And in his chest there was an unappreciated anxiety

in his heart were the thunderbolts of insults

And he kissed him in silence

as death blows the branches of roses. (Al-Shabbi 166)

Evening which comes with this state as the poet describes it raises a beautiful imagination in his soul that was missing for a long time. The poet blended his feeling with the aspects of nature around him because he did not find better than nature to resort to and express his complaints.

It brought back beautiful imagination

that was withheld by the calamities of the years

The miseries of distress circled it

and the steps of madness were given back. (Al-Shabbi 166)

3. The Night:

It seems that night has a special reality in the soul of Al-Shabbi, as he, like other Romantics, finds in darkness and night a symbol of misery, sorrow,and stillness. The night erases boundaries and differences and suggests liberation. The Romantic poet likes night because it is the world of unity in which the silence dominates and movement fades and succumbs to the calm he desires.The night is one of nature images in the poetry of Al-Shabbi that shares the poet's sorrows and misfortunes. Al-Shabbi's night is coloured with his feelings and emotions and the choice of night is not futile because it is characterized by fear and loneliness. He writes in his poem, AyuhaAllyal “O, Night”.

O night, father of misery and horror, 
terrible temple of life

Sweet brides of hope get down in you

pray with their beloved voice.

O night, you are a melodious sound

On the lips of ages between wailing. (Al-Shabbi 137).

\section{The Political Rebellion:}

Al-Shabbi rejected the situation of humiliation and subservience that his country was living under the shadow of a brutal colonist that does not know humanity and mercy. In the depth of every human being, there are repressed desires that are always looking for satisfaction in a society. The closest reason to explain Al-Shabbi's psyche is his saturation with ideas and principles of Romanticism that glorify freedom and reject all forms of restrictions. He did not aspire to political independence only but went beyond that to create an internal calm that assures the soul and brings stability.

In his famous poem, Iradat Al-Hyat "The Will of life", he tries to call people to fight for freedom and urge them against the colonization "This poem was the slogan of freedom and inspiration of revolutions in the Arab World from the gulf to the ocean" (Wahas 1792). It is the anthem of freedom and independence. He found in the particles of nature what he did not find in people. Al-Shabi borrowed many images from nature which later became an echo of his soul and secrets. Thus, the poet and nature have the same feeling of revolution, anger and rebellion.He writes:

If one day the people should choose life,

Fate is certain to respond.

The night will surely retreat, 
And fetters be broken.

The wind muttered between the ravines;

Over mountains and under trees

He who does not like scaling mountains

Will eternally in potholes.

When I asked the earth,

Mother, do you hate mankind?

She replied, I bless those with ambition

those who brave danger-

I curse the ones not keeping

step with time,

who are content live a fossil life

(Jayyusi and Nye 131-137)

\section{4- Spontaneity of Emotions and Love of Beauty:}

Romanticism built its philosophy on emotions and love of beauty. It shifted the focus from reason and logic to feelings and emotions. It gave absolute freedom to heart over mind. Wordsworth defines poetry as "the spontaneous overflow of powerful emotions" (Manjoh 204). Furthermore, in a letter to his friend- Al-Sanusi, Al-Shabbi defines poetry, "poetry is that what you hear and see in the wind's noise, and the roar of the sea. It is what you find in the trembling's breeze roses, upon which bees are buzzing and in the singing tone, sent in the ample space" (qtd. in Al-Tareefi 53).

The Romantics unleashed emotion and made it a holy god. They revered love and considered it a mean of transcendence and high virtue. Al-Shabbi sees that all the nature images 
are represented in his passion of love embracing the whole world. He also sees himself as a part of this existence and the existence is based on the image of a woman, for she is the creative nature who provides him her laps and wipes out his pains. Al-Shabbi raised women to the level of worship and this sanctification is mixed with the images of nature. He writes in his best love poem Salwat fi Haikal Alhub(Prayers in the Temple of Love):

You are endearing as childhood's

drifting melody,

limpid as the morning air.

Like a laughing sky, a moo-rich night

like roses, or a newborn smile.

What are you?

An image painted by heaven's sacred brush, an unexpected dawn

casting light over my life's pain?

You unveiled life's face

turned her cheek to me again.

You are the soul of the

spring is striding the earth

so even the proudest rose is moved.

(Jayussi and Shihab 117-119)

5. The Autumn:

It is an image of nature used by the poet in many places. The period of autumn celebrates not only Nature's beauty but also the transitoriness of life. It describes the attraction and richness 
of nature in autumn to show the power of sensual images of the poet.The poet used it to depict the situation of his country that was suffering under the cruelty of the French occupation to send a message to the colonizer that victory will come. He wants to tell him that after autumn and stillness there come thunders, winds, and horrors that symbolize the revolution and fury. AlShabbi devoted his poetry to his country-Tunisia. "He predicts the heroic struggle of his people against foreign occupation and tyranny and the certain downfall of the latter" (Badawi 164).

Hey, you, the unfair tyrant...

You, the lover of the darkness...

The enemy of life...

You've made fun of innocent people's wounds and your palm covered with their blood.

Wait, don't let the autumn, the clearness of the sky and the shine of the morning light fool you...

Because of the darkness, the thunder rumble and the blowing of the wind are coming toward you from the horizon Beware because there is a fire underneath the ash Who grows thorns will reap wounds The blood's river will sweep you away and you will be burned by the fiery storm. (Al-Shabbi 457)

\section{Conclusion}

Romantic poetry gave more priority to emotions more than reason and mind. His poetry embodies all characteristics of Romanticism,including nature. Al-Shabbi could deviate from the 
traditional way that was previously common in using nature. Nature became a mean to portray the situation that his people were living in during the French occupation. He used different images of nature, such as morning, evening, night, autumn and love to translate his philosophy towards life and people. For him, nature is the perfection he dreams and the love and tenderness that he does not find in society. 


\section{Works Cited}

Al-Bitar, Mohammed Shafiq. Nature's Image in the poetry of Al-Shabbi. Damascus University Journal - Volume 24 - Issue Three + Fourth,2008.Retrieved from https://rb.gy/gshdiw

Al-Shabbi, Abu Al-Qasim. Songs of Life.Trans. Lena Jayyusi and Naomi Shihab Nye. Carthage: Beit Al-Hikma, 1987.

Al-Tareefi, Yousif Atta. Abu Al-Qasim Al-Shabbi-Life and Poetry. Jordan, Dar Al-Ahlia for publishing and distributing, 2009.

Badawi, Muhammed Mustafa. A Critical Introduction to Modern Arabic Poetry. Cambridge [Eng: Cambridge UP, 1975.

Elbousty, Moulay Youness. “Abu al-Qasim al-Shabbi's 'The Will to Live': galvanising the Tunisian revolution”. The Journal of North African Studies, 2013 Vol. 18, No. 1, 159163.

Husni, Ronak. "Al-Shabbi and His Nature Poetry: Romantic or Revolutionary?" British Journal of Middle Eastern Studies 22.1-2 (1995): 81-92. JSTOR. Web. 09-09 2020.

Ismail, Azulluddin. Diwan Abu Al-Qasim Al-Shabbi. Beirut: Dar Al-Audah, 1972.

Kerru, Abul-Qasim Mohammad. AlShabbi: His Life and his Poetry. Beirut: Manshurat Dar Maktabat al-Hayat, 1952.

Manjoh, Priscillia M. Representations and Renegotiations of the Nation in Anglophone Cameroonian Literature. Lit Verlag, 2019.

Schütze, Martin. "Studies in the Mind of Romanticism. I. Romantic Motives of Conduct in Concrete Development. The Letters of Heinrich Von Kleist to Wilhelmine Von Zenge.” Modern Philology, vol. 16, no. 6, 1918, pp. 281-296. JSTOR, www.jstor.org/ stable/ 433211. Accessed 10 Nov. 2020. 
Speight, R. Marston. "A Modern Tunisian Poet: Abu Al-Qasim al-Shabbi (19091934)."International Journal of Middle East Studies 4.2 (1973): 178-189.

Wahas, Yazid Meftah Ali. Role of Literature in Arabic Society: Abu Al-Qasim Al-Shabbi as a Model for Romantics.Smart Moves Journal Ijellh, 6(12), 14. Retrieved from https://ijellh.com/OJS/index.php/OJS/article/view/6162, 2018.

Sabiha,Petroni\&Alim Naima. The image of nature in the poetry of Al-Shabbi.Algeria, Albouira 2011. 